\title{
The Romanian National Breast Reconstruction Program - Results and Conclusions after 5 Years
}

\author{
Catalin Gheorghe BEJINARIU', Silviu Adrian MARINESCU', Mircea Dan ENESCU²
}

\begin{abstract}
Introduction: The optimization of the breast reconstruction treatment protocols and the introduction of state-subsidized national programs are global priorities. The present paper presents the results obtained within the National Program of Breast Reconstruction at the "Bagdasar-Arseni" Emergency Clinical Hospital, highlighting the advantages and disadvantages of the surgical techniques used. Materials and Methods: The results obtained after 71 surgical interventions were used for the study. The methodology used involved the use of demographic data, patient history, and the description of the surgical methods and techniques that were used. Results: Among the main results, the paper highlights the fact that mammary reconstruction by using the 'expander-implant' surgical technique was 5 times more frequent than the „implant-myocutaneous flap" technique. Post-operative complications have been present in $57 \%$ of the patients who associate comorbidities. Breast reconstruction using the TRAM (transverse rectus abdominis muscle ${ }^{1}$ ) flap was the rescue solution for severe complications. Conclusions: The TRAM flap was proven to be the best technique in the treatment of difficult cases. Carrying out these statistical analyzes related to projects of a national scale form the solid foundation of documented studies that bring a significant contribution to the development of the Romanian medical system.
\end{abstract}

Keywords: breast reconstruction, mastectomy, silicone implants, breast expander, TRAM flap.

\section{Rezumat}

Introducere: Optimizarea protocoalelor de tratament reconstructiv la nivelul sânului și introducerea programelor naționale subvenționate de stat constituie priorități la nivel mondial. Lucrarea de față prezintă rezultatele obținute în cadrul Programului Național de Reconstrucție mamară în Spitalul Clinic de Urgență „Bagdasar-Arseni", subliniind avantajele și dezavantajele tehnicilor chirurgicale folosite. Materiale și metode: Pentru realizarea studiului au fost utilizate rezultatele culese în urma a 71 de intervenții chirurgicale efectuate. Metodologia folosită a implicat utilizarea datelor demografice, istoricului pacientelor, precum și descrierea metodelor și tehnicilor chirurgicale folosite. Rezultate: Dintre principalele rezultate, lucrarea evidențiază faptul că reconstrucția mamară prin utilizarea tehnicii chirurgicale "expander-implant" a fost de 5 ori mai frecventă decât tehnica asocierii implantului cu lambouri miocutanate. Complicațiile post-operatorii au fost remarcate la peste jumătate dintre pacientele care asociază comorbidități. Reconstrucția mamară prin utilizarea lamboului TRAM (transverse rectus abdominis muscle) a reprezentat soluția salvatoare în cazul complicațiilor severe apărute. Concluzii: Lamboul TRAM se dovedește a fi tehnica optimă folosită pentru tratamentul cazurilor dificile. Realizarea acestor analize statistice în cadrul proiectelor de anvergură națională constituie fundația solidă a unor studii documentate care aduc o contribuție semnificativă la dezvoltarea sistemului medical românesc.

Cuvinte-cheie: reconstrucție mamară, mastectomie, implant siliconic, expander mamar, lambou TRAM.

1 Department of Plastic and Reconstructive Surgery, „BagdasarArseni" Emergency Clinical Hospital, Bucharest, Romania

2 Department of Plastic and Reconstructive Surgery, "Grigore

Alexandrescu" Emergency Clinical Hospital, Bucharest, Romania
Corresponding author.

Catalin Gheorghe Bejinariu, Department of Plastic and Reconstructive Surgery, „Bagdasar-Arseni” Emergency Clinical Hospital, Bucharest, Romania.

E-mail: drbejinariu@gmail.com 


\section{INTRODUCTION}

Breast cancer treatment is a priority for the health system regardless of the state, the culture and the economic context. As it emerges from the most recent report of the American Society for Cancer Treatment published in early July 2018, the incidence of breast cancer $^{2}$ is on the rise. The majority of breast cancer cases occurred in women aged 40-44 and 45-49 years $(77.3 \%)^{3}$. The encouraging statistics of the decrease in mortality caused by this condition was based on the improvement of early diagnosis systems as well as the efficient standardization of the operative protocols for the treatment of this condition.

Challenges related to the breast cancer treatment are not recent ones, the complexity of the pathophysiological phenomena involved in the onset and progression of this disease, as well as the increased mortality rate in the female population, drew attention to this phenomenon, requiring the development of performance protocols ${ }^{4}$ referring to the total excision of the involved malignant tumor. Treatment with curative intent often involves the excision of large tissue fragments or even the entire affected breast, and the need for further reconstruction is easily understood in this context.

The „Breast Reconstruction Program for Oncological Diseases" aims to facilitate the access to breast reconstruction of as many patients as possible and to integrate these patients from a social and professional point of view by achieving a pleasing aesthetic aspect. The program involves paying the cost of breast prosthesis and surgery by the National Health Insurance House, so that patients who have undergone mastectomy ${ }^{5}$ for the treatment of breast cancer can benefit from free breast reconstruction. According to the patients, the true closure of this unpleasant chapter in their lives is the reconstruction of the breast, thus avoiding the traumatic memories associated with their past medical condition.

Further, the opportunity to achieve the reconstruction of the affected breast in the same surgical procedure with oncological resection is supported by the fact that the patients diagnosed in incipient stages have a favorable post-operative evolution without complications; also, the reduction of the hospitalization time and the reduced financial resources allocated are advantages that support the use of this treatment protocol.

The evolution of screening methods and media campaigns for the awareness of the severity of this affection have resulted in an increase in the early diagnosis of breast cancer. Therefore, a growing number of patients benefit from a treatment consisting of partial excision of the mammary gland, followed by reconstruction during the same surgical procedure.

\section{MATERIALS AND METHODS}

The research presents the results of the statistical analysis of the variables collected during the 5 years since the onset of the National Breast Reconstruction Program (2014-2019) conducted at the „BagdasarArseni” Emergency Clinical Hospital, centralizing information and medical parameters of general interest related to the treatment of patients who underwent 71 surgical procedures for the reconstruction of breasts after mastectomy.

In order to carry out the global statistical analysis, a wide range of information was introduced into the database: topographic, morphological, occupational, institutional and academic.

In order to cover the whole spectrum of the knowledge related to this program, the research also used a series of variables that do not make the objective of the present material, the present paper being mainly focused on the following assessments:

- the comparative analysis of the different surgical techniques used;

- the impact of the comorbidities on the postoperative evolution, as well as medium and longterm prognosis;

- the influence of the adherence ${ }^{6}$ to treatment related to the patients involved in study;

- the average length of hospitalization as a predictive factor of postoperative prognosis;

- the comparative analysis of the results with data obtained from international literature;

- determining the advantages of continuing the program based on the results obtained so far.

In elaboration of the research project, a special importance was given to the postoperative complications, the understanding of the mechanism and the context of their appearance, representing an extremely important aspect regarding the optimization of the treatment protocol.

\section{Collection and statistical analysis of data}

The reviewed cases were related to patients that match the classical inclusion criteria recommended by the Romanian Ministry of Health, as follows:

- medical history of radical or limited mastectomy in the context of breast cancer; 
- the presence of the oncological assessment that explicitly endorses the indication of breast reconstruction;

- patients' agreement to perform the reconstructive surgery.

The exclusion criteria recommended by the National Mammary Reconstruction Program have been applied by not using data gathered from patients with severe systemic disorders that contraindicate reconstructive surgery or patients that are still in the oncological treatment program.

The statistical data and information collected within the project were processed in order to obtain results of general interest and to elaborate a complex database which, to the extent that this is feasible, is the foundation of an integrated project that provides an overview of the effects of the National Breast Reconstruction Program.

For analyzing the quantitative data the basic criteria of statistical analysis were used, focusing our attention on studying the Gaussian distribution in order to identify possible deviations from the normal parameters. Therefore, variables such as age, weight, height and blood pressure were entered into the database, with the desire to make a more detailed presentation of the results of this study. The calculations required for the statistical analysis refer to the averages, the standard deviations, as well as the statistical significance of the processed information.

The analysis of the qualitative variables was based on the understanding of:

- the implications of the different reconstruction techniques used;

- the location of the tumor as a defining factor of the therapeutic protocol;

- the complications that occurred;

- the influence of the complications on the aesthetic prognosis;

- the total duration of the treatment;

- personal and family medical history ${ }^{7}$;

- obtaining symmetry;

- the patients' satisfaction ${ }^{8}$ at the end of treatment.

\section{RESULTS}

The present analysis aims to cover the whole spectrum of the breast reconstruction phenomenon, therefore the research presents both the parameters specific for the surgical discipline and the biochemical variables that can contribute to the improvement of the postoperative prognosis.
The most relevant data and information were selected from the established database in order to emphasize the targeted objectives:

\section{Demographic data}

The average age of the patients in the above mentioned program was $50.88 \pm 10.11$ years, the youngest patient included in the study being 33 years old and the oldest being 68 years old.

The urban environment was the source of residence for $100 \%$ of the patients included in the study, the access to specialized medical services being limited for patients located in rural areas ${ }^{9}$.

\section{Medical history}

Elevated blood glucose levels ${ }^{10}$ were noted for $30.30 \%$ of the determinations, this being an important prognostic factor in this study.

The history of chemotherapy was present in $38.79 \%$ of the patients included in the study, its association having moderate consequences on postoperative prognosis, both functional (structural) and esthetic.

History of radiation therapy was present in $65.21 \%$ of the patients, with a strong impact on local complications such as wound dehiscence, marginal necrosis, and infection ${ }^{11}$.

\section{Surgical reconstructive interventions}

The silicone implants were used in $82.35 \%$ of the patients who were included in the study, $52.94 \%$ of whom benefited from the left breast reconstruction (Figure 1).

The mammary expanders ${ }^{12}$ were part of the reconstructive algorithm in the case of $76.47 \%$ of the patients, from which $46.15 \%$ being used to expand tissues from the left breast.

TRAM flap reconstruction was the therapeutic solution in $11.76 \%$ of patients, the laborious therapeutic protocol being a discouraging factor for the patients included in this study.

\section{Associated surgical techniques}

The „tissue expander - silicone implant” surgical technique (Figure 2) was present in $52.94 \%$ of the patients, the rest of the patients benefiting from other reconstructive methods (Figure 3 ).

The „silicone implant - TRAM flap” surgical technique (Figure 4) was the therapeutic solution for $11.76 \%$ of the patients, the relatively small percentage being the consequence of the refusal of the use of this 


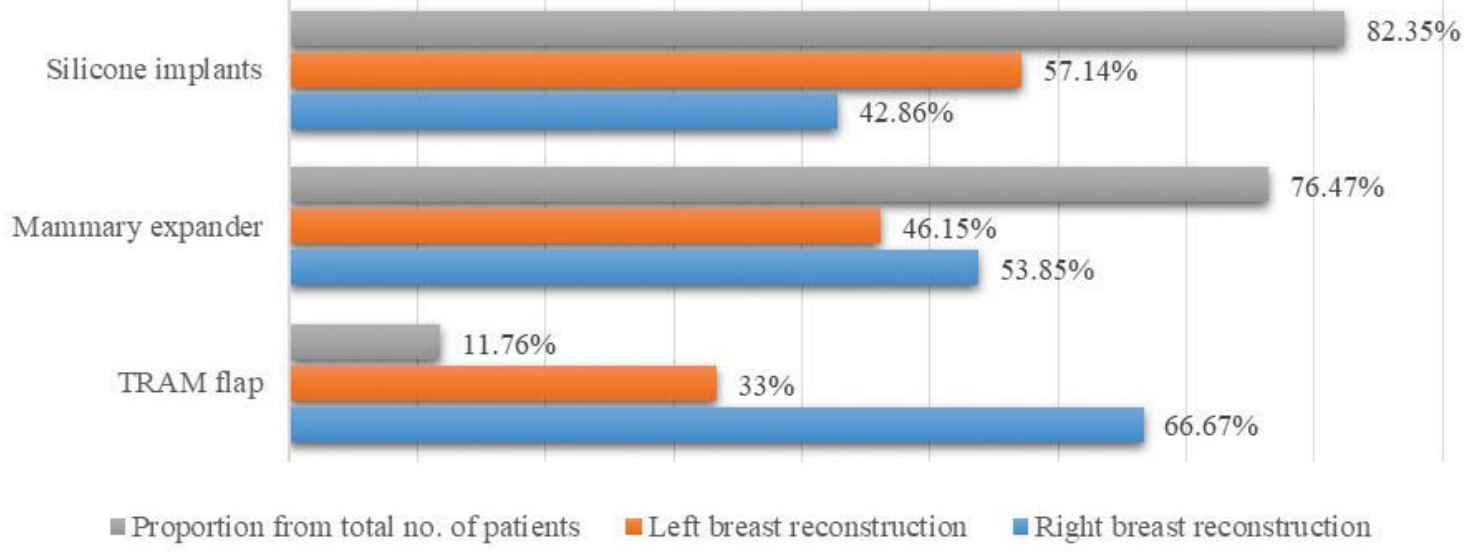

Figure 1. Types of surgical interventions associated with breast topography (Source: authors).

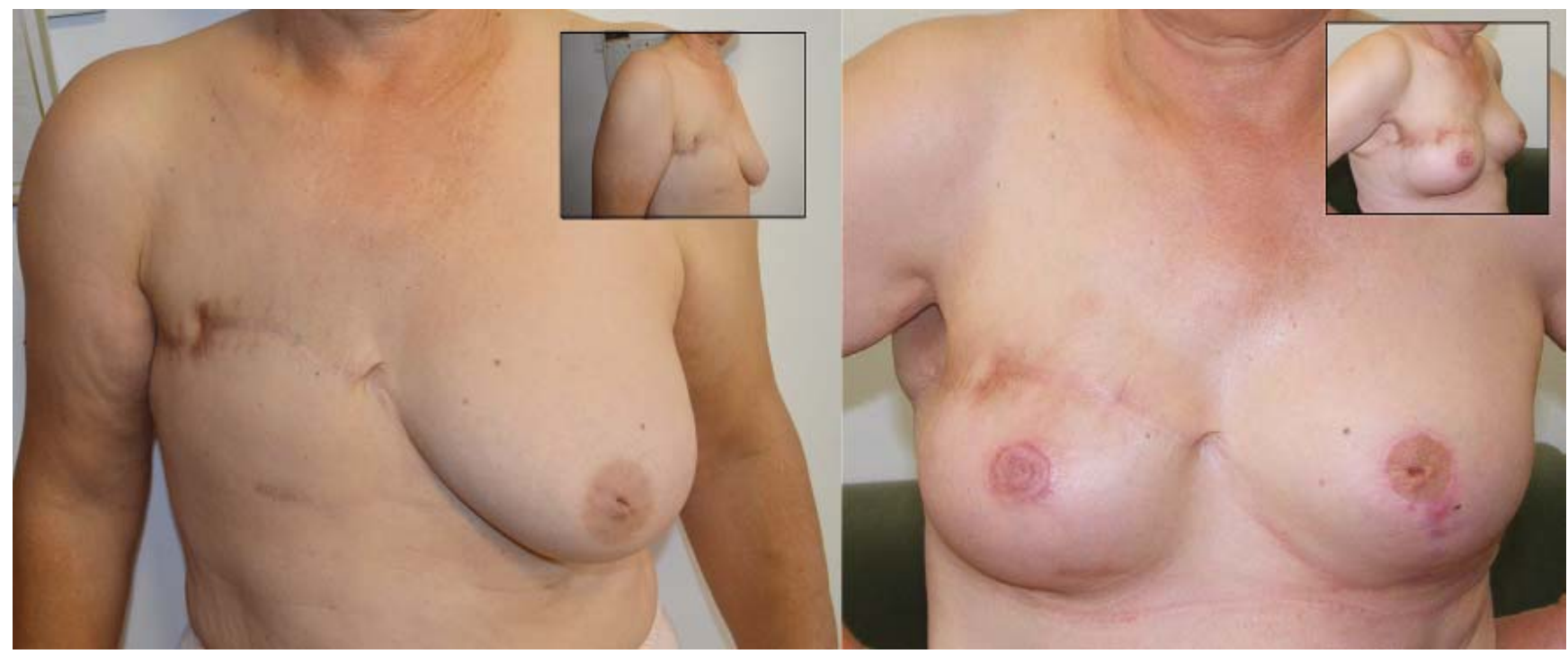

Figure 2. Breast reconstruction using the 'expander-implant' surgical technique (Source: authors).

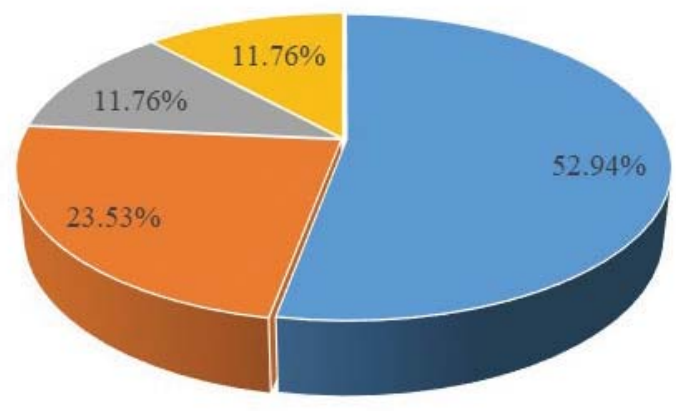

- Tissue expander - silicone implant =Implant " Silicone implant - TRAM flap " Expander

Figure 3. Types of surgical techniques (Source: authors). 

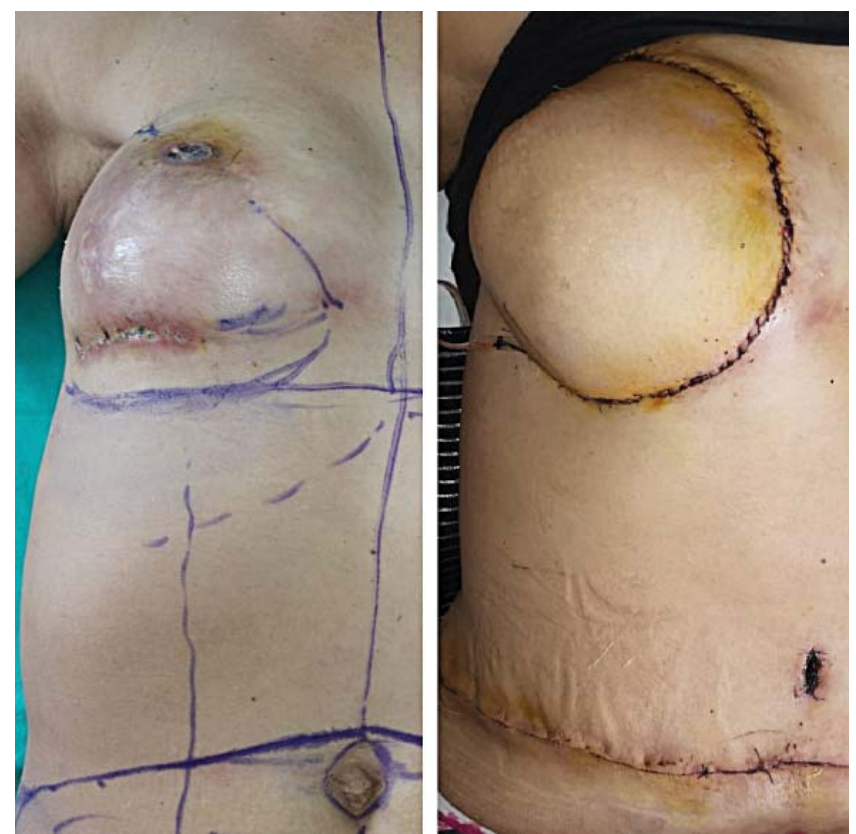

Figure 4. Breast reconstruction using the TRAM flap surgical technique (Source: authors).

type of reconstruction by the patients included in the study ${ }^{13}$.

The 'silicone implant - TRAM flap' surgical technique was used in $100 \%$ of the patients with severe complications (such as wound dehiscence and infection).

\section{Aesthetic procedures}

Breast asymmetry correction surgery was performed in all patients included in the study, the necessity of this procedure being established as a basic criterion from the beginning of the reconstructive treatment plan.

Reconstruction of the areola ${ }^{14}$ using a medical tattoo was performed in $73 \%$ of the patients, $25 \%$ benefiting from plastic reconstruction with free skin graft from the contralateral areola.

\section{Duration of hospitalization}

The average hospitalization time is 5.93 days with a minimum value of 2 days/intervention and a maximum value of 18 days/intervention. Shorter hospitalization times were associated with a higher degree of satisfaction (Figure 5). Figure 5 illustrates the number of hospitalization days as percentages with a maximum value of $100 \%$ for the maximum amount of hospitalization days (18 days) and $0 \%$ for the minimum amount ( 2 days). The patients' degree of satisfaction was rated from 0 to 10 and also illustrated as percentages with the highest degree of satisfaction being 10 or $100 \%$ and the lowest degree being 0 or $0 \%$.

\section{Postoperative results}

Pathological personal history was associated in 57\% of cases with the occurrence of postoperative complications, such as wound dehiscence and local infection being the main factors contributing to this percentage, the statistical significance $(p<0.029)$ of this association being representative within the studied group.

Postoperative complications occurred in 29.41\% of the patients included in the study, the opening of the surgical wound (dehiscence) being the main factor contributing to this percentage.

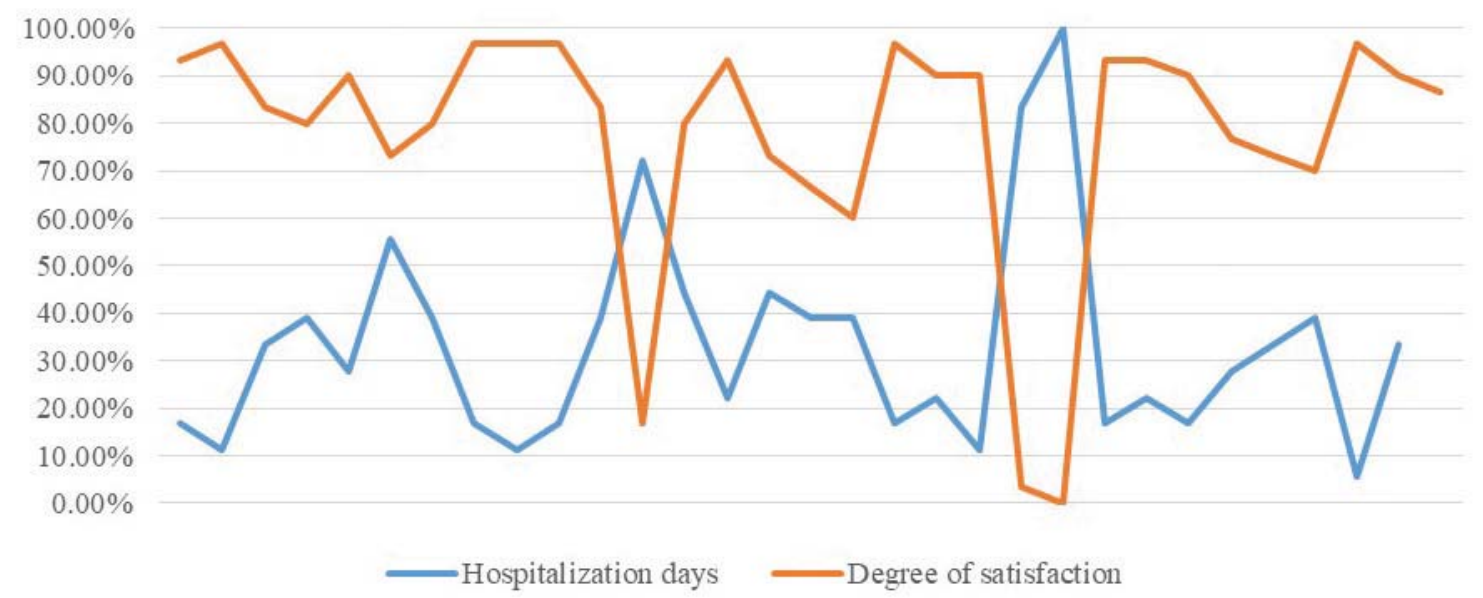

Figure 5. Correlation between number of hospitalization days and degree of satisfaction (Source: authors). 


\section{DISCUSSIONS}

The implementation of a large-scale national program such as breast reconstruction after oncological diseases is, without a doubt, a positive initiative, which facilitates patients' access to medical services, especially patients who have undergone radiation or limited mastectomy, therefore having a significant contribution to the rapid socio-professional reintegration of these patients. The increased incidence of breast cancer in younger patients ${ }^{15}$ and the increased mortality rate of this subgroup raises the problem of early diagnosis of the disease followed by radical tumor excision and immediate reconstruction with the hope of a quick recovery without consequences ${ }^{16}$.

The statistical analysis revealed that the use of classical breast reconstruction techniques ${ }^{17}$, using tissue expanders and silicone implants, is an effective measure for the recovery of these patients. Whether we are talking about immediate implant reconstruction or two-step reconstruction after the initial tissue expansion, the duration of hospitalization is reduced when using prosthetic materials, the results are predictable and offer a high degree of patient satisfaction.

The aesthetic result obtained by the use of flaps (TRAM, DIEP (deep inferior epigastric perforators ${ }^{18}$ ), latissimus dorsi) offers many advantages both aesthetically and from the point of view of postoperative monitoring of the neoplastic disease, but within the studied group difficulties were encountered in obtaining adherence to treatment, refusing these complex surgical techniques and opting for the use of synthetic reconstructive materials.

The use of complex reconstruction methods involving the use of myocutaneous flaps is an extremely good solution for solving these cases, also representing a rescue solution in case of complications caused by reconstruction using silicone breast prostheses. The study showed that reconstruction using TRAM flaps were a safety belt for solving complicated cases marked by postoperative complications.

Radiotherapy had significant consequences on the postoperative outcome ${ }^{19}$, either short, medium or long term. Postoperative wound dehiscence, marginal necrosis and infection ${ }^{20}$ were just some of the immediate local complications that have been observed in these patients. Capsular contraction was determined as the main complication occurring medium to long term within this group.

Regarding the biochemical parameters studied during the elaboration of the project, among the 429 variables included in the database, changes in blood glucose values showed the highest statistical relevance in terms of postoperative prognosis. Regardless of the surgical technique used, the average duration of hospitalization in patients with high blood glucose levels was increased compared to the group of patients with normal blood glucose. The risk of immediate postoperative complications is also higher in patients who have had high blood glucose levels.

In terms of transaminase and coagulation time, no significant variations were noted that would result in changes related to the protocol and therapeutic approach of these patients. There were no significant changes in the haemogram within the studied group, so no additional recommendations can be made other than the classical ones, regarding the careful monitoring of the number of white blood cells, hemoglobin and platelets. Careful analysis of these parameters has been shown to be helpful in avoiding immediate postoperative complications of dehiscence and infection ${ }^{21}$.

The research shows that a particular attention has to be paid to personal pathological antecedents as a predictor of postoperative evolution, statistical analysis reflecting an increased association of septic complications and skin necrosis in the group of diabetic patients.

Patient access to specialized healthcare as well as basic health education are important elements to be highlighted. As shown by the statistical analysis related to demographic data, all the patients included in the study come from the urban environment, a factor that advocates for the improvement of the rural medical infrastructure, so that an increased number of patients can also have access to these surgeries.

Another aspect to be mentioned is that of effective doctor-patient communication, so that the patients' expectations are actually realistic in relation with the postoperative aesthetic prognosis.

\section{CONCLUSIONS}

The main goal of breast reconstruction surgery is the rapid and effective socio-professional integration of the patient. The psychological factor is essential and extremely important for solving these cases. The doctor-patient interaction should be focused on the understanding of the therapeutic options and the possible results of the intervention; following, the patients' feedback and expectations are to be considered during the elaboration of the surgical protocol.

The reduced duration of hospitalization was associated with high patient satisfaction and increased adhe- 
rence to treatment. Consequently, the use of reconstruction techniques using the silicone breast prosthesis, associated or not associated with an expander, was the main therapeutic solution applied and appreciated by the patients.

The association of radiation history has involved a negative prognostic factor and required a careful analysis of the therapeutic options, as well as good preoperative communication with patients so that they are fully aware of the possible complications that may arise in this situation.

Increased blood glucose levels are a predominant predictor of postoperative complications, particularly dehiscence and infection.

The government subsidy of the surgical intervention and the prosthetic material is an extremely important factor in the rapid socio-professional reintegration of these patients, as evidenced by the anamnesis performed prior to surgical interventions. The economic factor often resembles a barrier to accessing this surgical

\section{References}

1. Jeong, W., Lee, S., Kim, J., 2018. Meta-analysis of flap perfusion and donor site complications for breast reconstruction using pedicled versus free TRAM and DIEP flaps, The Breast, Volume 38, pp. 45-1.

2. Akram, M., Iqbal, M., Daniyal, M., Khan, A.U., 2017. Awareness and current knowledge of breast cancer, Biological Research, pp. 1-23.

3. Shoemaker, M. L., White, M. C., Wu, M., Weir, H. K., Romieu, I., 2018. Differences in breast cancer incidence among young women aged $20-49$ years by stage and tumor characteristics, age, race, and ethnicity, Breast Cancer Research and Treatment, volume 169, issue 3, pp. 595-606.

4. Soon, P. S., Ruban, S., Mo, H.T.J., Lee, R. Saliba, L., Shah, A., Segara D., Yarrow, S., Girgis, A., 2018. Understanding patient choices regarding breast reconstruction after mastectomy for breast cancer, Supportive Care in Cancer, pp. 1-8.

5. Metcalfe, K. A., Semple, J., Quan, M. L., Holloway, C., Wright, F., Narod, S., Hofer, S., Bagher, S., Zhong, T., 2017. Why Some Mastectomy Patients Opt to Undergo Delayed Breast Reconstruction: Results of a Long-Term Prospective Study, Plastic and Reconstructive Surgery: Volume 139, Issue 2, pp. 267-275

6. Zhang, C., Hu, G., Biskup, E., 2018. Correction to: Depression Induced by Total Mastectomy, Breast Conserving Surgery and Breast Reconstruction: A Systematic Review and Meta-analysis, World Journal of Surgery, Volume 42, Issue 7, pp. 2086-2086.

7. Stan, I. G., Jecan, C. R., Stefanescu, O., Raducu, L., Neagu, T. P., Lascar, I., 2018. Results in Breast Reconstruction - Retrospective Study, Modern medicine, Volume 25, No. 3, pp. 149-157.

8. Matthews, H., Turner, A., Wiliamson, I., Clyne, W., 2018. 'It's a silver lining': A template analysis of satisfaction and quality of life following post-mastectomy breast reconstruction, British journal of Health Psychology, Volume 23, Issue 2, pp. 455-475.

9. Prusaczyk, B., Maki, J., Luke, D. A., Lobb, R., 2018. Rural Health Networks: How Network Analysis Can Inform Patient Care and Organizational Collaboration in a Rural Breast Cancer Screening Network, The Jurnal of Rural Helth. reconstructive treatment for these patients, therefore the introduction of this program is welcome, maintaining it being the guarantee of solving a growing number of cases.

This paper represents a first step in a series of informative materials dedicated to understanding the impact of the National Breast Reconstruction Program and can bring a significant contribution to further research and extended statistical analysis related to other medical units involved in this program.

\section{Compliance with ethics requirements:}

The authors declare no conflict of interest regarding this article.

The authors declare that all the procedures and experiments of this study respect the ethical standards in the Helsinki Declaration of 1975, as revised in 2008(5), as well as the national law. Informed consent was obtained from all the patients included in the study.

10. Law, T. Y., Moeller, E., Hubbard, Z. S., Rosas, S., Andreoni, A., Chim, H. W., December 2018. Preoperative Hypoglycemia and Hyperglycemia Are Related to Postoperative Infection Rates in Implant-Based Breast Reconstruction, Journal of Surgical Research Volume 232, pp. 437-441.

11. Vitali, A., Stephen, L., Douglas, W. S., 2018. Surgeon-Controlled Comparison of Direct-to-Implant and 2-Stage Tissue Expander-Implant Immediate Breast Reconstruction Outcomes, Annals of Plastic Surgery, Volume 80, issue 3, pp. 212-216.

12. Makiguchi, T., Atomura, D., Nakamura, H., Fujii, T., Yokoo, S., 2019. Quantitative assessment and risk factors for chest wall deformity resulting from tissue expansion for breast reconstruction, Breast Cancer, doi: 10.1007/s12282-018-00942-3, pp. 1-6.

13. Lifford, K. J., Witt, J., Burton, M., Collins, K., Caldon, L., Edwards, A., Reed, M., Wyld, L., Brain, K., 2015. Understanding older women's decision making and coping in the context of breast cancer treatment, BMC Medical Informatics and Decision Making, pp. 1-12.

14. Nagura-Inomata, N., Iwahira, Y., Hayashi, N., Komiya, T., Takahashi, O., 2016. The optimal reconstruction size of nipple-areola complex following breast implant in breast cancer patients, SpringerPlus, pp. 1-7.

15. Christophe, V., Duprez, C., Congard, A., Antoine P., Lesur A., Fournier E., Vanlemmens, L., 2015. The subjective experience of young women with non-metastatic breast cancer: the Young Women with Breast Cancer Inventory, Health Qual Life Outcomes. https://doi.org/10.1186/s12955-015-0273-x, pp. 1-12.

16. Otterburn, D. M., 2015. Problems in Breast Surgery: A Repair Manual, Aesthetic Plastic Surgery, Volume 39, Issue 3, pp. 398398.

17. Seth, A. K., Allen Jr., A. R., 2018. Modern techniques and alternative flaps in microsurgical breast reconstruction, Journal of Surgical Oncology, Volume 118, Issue 5, pp. 768-779.

18. Wade, R. G., Razzano, S., Sassoon, E. M., Haywood, R. M., Wormald, J. C. R., Figus, A., 2017. Correction to: Reply to "Complications in DIEP Flap Breast Reconstruction After Mastectomy 
for Breast Cancer: A Prospective Cohort Study Comparing Unilateral Versus Bilateral Reconstructions", Volume 24, Supplement 3, pp. 683-683.

19. Steele, K. H., Macmillan, R. D., Ball, G. R., Akerlund, M., McCulley, S. J., 2018. Multicentre study of patient-reported and clinical outcomes following immediate and delayed Autologous Breast Reconstruction And Radiotherapy, Volume 71, Issue2, pp. 185193.
20. Barbieri, R., Pesce, M., Franchelli, S., Baldelli, I., De Maria, A., Marchese, A., 2015. Phenotypic and genotypic characterization of Staphylococci causing breast peri-implant infections in oncologic patients, BMC Microbiology, https://doi.org/10.1186/ s12866-015-0368-x, pp. 1-10.

21. Connors, S. K., Goodman, M. S., Myckatyn, T., Margenthaler, J., Gehlert, S., 2016. Breast reconstruction after mastectomy at a comprehensive cancer center, SpringerPlus, pp. 1-9. 